\title{
Influence of the gallbladder on serum bile acids
}

\author{
CR PENNINGTON, $*$ PE ROSS, $†$ IAN AD BOUCHIER $†$ \\ From the * Medical Unit, Kings Cross Hospital, Dundee, and the †Department of Medicine, Ninewells \\ Hospital and Medical School, Dundee
}

SUMMARY Serum bile acids (SBA) were studied after a standard fatty meal in patients with gallbladder disease. Early postprandial bile acid values were found to be greater in patients with non-functioning gallbladders. Higher postprandial SBA values were found after cholecystectomy. Serum bile acid measurements were of no value in the assessment of gallbladder function.

Serum bile acid (SBA) concentrations are known to be increased in patients with liver disease, ${ }^{1}$ and the measurement of SBA has been advocated in the evaluation of liver disease. ${ }^{2}$ Because bile acids undergo an enterohepatic circulation ${ }^{3}$ disease of the gallbladder intestine and portal circulation might also be expected to influence SBA. The purpose of this study was to evaluate the influence of the gallbladder on SBA in order to assess any role SBA values may have in monitoring gallbladder function.

\section{Patients and methods}

Patients who had been investigated for upper abdominal pain were studied. Six were found to Accepted for publication 16 December 1981 have "non-functioning" gallbladders after an oral cholecystogram and intravenous cholangiogram. Seven patients were similarly identified as having functioning or poorly functioning gallbladders which contained gallstones. Seven healthy subjects acted as controls.

After fasting serum samples had been obtained, each subject was given a fatty meal consisting of 40 $\mathrm{ml}$ of Prosparol (an emulsion containing 50\% arachis oil) in $160 \mathrm{ml}$ of water. Further samples were taken at 15 minute intervals for $2 \mathrm{~h}$. A second sequence was obtained in 9 of these subjects 6 months after cholecystectomy.

Radioimmunoassay methods ${ }^{4}$ were used to measure conjugates of cholic acid, and chenodeoxycholic acid. Differences between groups were compared for significance with Student's $t$ test.

Table 1 Sequential SBA concentrations after fatty meal in patients with gallbladder disease (mean $\pm S D$ ( $\mu m o l / l)$

\begin{tabular}{|c|c|c|c|c|c|c|c|c|c|}
\hline & \multicolumn{9}{|c|}{ Time $(\min )$} \\
\hline & 0 & 15 & 30 & 45 & 60 & 75 & 90 & 105 & 120 \\
\hline $\begin{array}{l}\text { Controls } \\
\text { Non-functioning } \\
\text { gallbladder } \\
\text { Gallstones }\end{array}$ & $\begin{array}{r}\text { Cholyl c } \\
0.46 \\
\pm 0.17 \\
0.72 \\
\pm 0.46 \\
0.51 \\
\pm 0.17\end{array}$ & $\begin{array}{c}\text { jugates } \\
0.49 \\
\pm 0.13 \\
0.97^{* * *} \\
\pm 0.33 \\
0.56 \\
\pm 0.12\end{array}$ & $\begin{array}{c}1.01 \\
\pm 0.38 \\
1.95^{* *} \\
\pm 0.84 \\
1.13 \\
\pm 0.57\end{array}$ & $\begin{array}{r}1.90 \\
\pm 1.10 \\
2.57 \\
\pm 1.17 \\
1.40 \\
\pm 0.90\end{array}$ & $\begin{array}{r}2.44 \\
\pm 1.37 \\
3.10 \\
\pm 2.20 \\
2.14 \\
\pm 0.77\end{array}$ & $\begin{array}{r}2.74 \\
\pm 1.56 \\
2.58 \\
\pm 1.96 \\
2.60 \\
\pm 1.36\end{array}$ & $\begin{array}{r}2.78 \\
\pm 0.93 \\
2.28 \\
\pm 1.47 \\
3.23 \\
\pm 1.47\end{array}$ & $\begin{array}{r}3.00 \\
\pm 2.15 \\
2.82 \\
\pm 2.14 \\
3.33 \\
\pm 2.37\end{array}$ & $\begin{array}{r}3.39 \\
\pm 2.46 \\
2.13 \\
\pm 1.89 \\
3.47 \\
\pm 2.60\end{array}$ \\
\hline $\begin{array}{l}\text { Controls } \\
\text { Non-functioning } \\
\text { gallbladder } \\
\text { Gallstones }\end{array}$ & $\begin{array}{c}\text { Chenode } \\
0.86 \\
\pm 0.50 \\
1.43 \\
\pm 1.30 \\
0.97 \\
\pm 0.52 \\
\end{array}$ & $\begin{array}{c}y \text { cholyl cor } \\
0.84 \\
\pm 0.24 \\
1.60^{*} \\
\pm 0.80 \\
1.10 \\
\pm 0.55\end{array}$ & $\begin{array}{c}\text { jugates } \\
1.64 \\
\pm 0.50 \\
3.25^{*} \\
\pm 2.00 \\
1.80 \\
\pm 0.90 \\
\end{array}$ & $\begin{array}{r}2.57 \\
\pm 1.58 \\
4.60 \\
\pm 3.60 \\
2.23 \\
\pm 1.45 \\
\end{array}$ & $\begin{array}{r}4.68 \\
\pm 2.37 \\
4.88 \\
\pm 3.38 \\
3.70 \\
\pm 1.18 \\
\end{array}$ & $\begin{array}{r}5.00 \\
\pm 3.95 \\
3.82 \\
\pm 2.67 \\
3.82 \\
\pm 1.80 \\
\end{array}$ & $\begin{array}{r}5.51 \\
\pm 2.55 \\
3.45 \\
\pm 2.20 \\
5.30 \\
\pm 2.48 \\
\end{array}$ & $\begin{array}{r}4.59 \\
+2.82 \\
4.25 \\
+3.57 \\
4.36 \\
+2.39 \\
\end{array}$ & $\begin{array}{r}5.22 \\
+3.63 \\
3.70 \\
\pm 2.70 \\
4.78 \\
+2.54 \\
\end{array}$ \\
\hline $\begin{array}{l}{ }^{*} p<0.05 \\
{ }^{* *} p<0.02 \\
{ }^{* * *} p<0.005\end{array}$ & & & & 754 & & & & & \\
\hline
\end{tabular}


Table 2 Sequential SBA concentration after fatty meal in patients before and after cholecystectomy (mean $\pm \operatorname{SD}(\mu m o l / l)$

\begin{tabular}{|c|c|c|c|c|c|c|c|c|c|}
\hline & \multicolumn{9}{|c|}{ Time (min) } \\
\hline & 0 & 15 & 30 & 45 & 60 & 75 & 90 & 105 & 120 \\
\hline $\begin{array}{l}\text { Preop } \\
\text { Postop }\end{array}$ & $\begin{array}{c}\text { Cholyl } \\
0.55 \\
\pm 0.32 \\
0.90 \\
\pm 0.60\end{array}$ & $\begin{array}{r}\text { jugates } \\
0.76 \\
\pm 0.28 \\
1.20 \\
\pm 0.59\end{array}$ & $\begin{array}{r}1.49 \\
\pm 0.86 \\
2.06 \\
\pm 0.62\end{array}$ & $\begin{array}{r}1.93 \\
\pm 1.20 \\
2.50 \\
\pm 0.53\end{array}$ & $\begin{array}{r}2.71 \\
\pm 1.90 \\
2.90 \\
\pm 0.90\end{array}$ & $\begin{array}{r}2.30 \\
\pm 1.80 \\
3.40 \\
\pm 1.20\end{array}$ & $\begin{array}{r}2.24 \\
\pm 1.33 \\
3.10 \\
\pm 1.57\end{array}$ & $\begin{aligned} & 1.52 \\
& \pm 0.96 \\
& 3.35^{*} \\
& \pm \\
& \pm 1.72\end{aligned}$ & $\begin{array}{c}1.43 \\
\pm 0.59 \\
2.93^{*} \\
\pm 1.68\end{array}$ \\
\hline $\begin{array}{l}\text { Preop } \\
\text { Postop }\end{array}$ & $\begin{array}{c}\text { Chenod } \\
1.00 \\
\pm 0.75 \\
1.80 \\
\pm 1.20\end{array}$ & $\begin{array}{r}y \text { cholyl } \\
1.30 \\
\pm 0.69 \\
2.20 \\
\pm 1.08\end{array}$ & $\begin{array}{r}\text { jugates } \\
2.40 \\
\pm 1.60 \\
3.68 \\
\pm 0.80\end{array}$ & $\begin{array}{r}3.08 \\
\pm 1.88 \\
4.70 \\
\pm 0.96\end{array}$ & $\begin{array}{r}4.30 \\
\pm 2.75 \\
5.00 \\
\pm 1.60\end{array}$ & $\begin{array}{r}3.00 \\
\pm 2.19 \\
6.00 \\
\pm 2.70\end{array}$ & $\begin{array}{r}3.89 \\
\pm 2.99 \\
5.10 \\
\pm 2.96\end{array}$ & $\begin{array}{c}2.58 \\
\pm 1.60 \\
6.00^{*} \\
\pm 3.20\end{array}$ & $\begin{array}{c}2.50 \\
\pm 0.98 \\
4 \cdot 60^{*} \\
\pm 1.80\end{array}$ \\
\hline
\end{tabular}

${ }^{*} \mathrm{p}<0.05$

\section{Results}

\section{POSTPRANDIAL PROFILES IN PATIENTS WITH}

GALLBLADDER DISEASE

Serum bile acid values are summarised in Table 1 . There was little difference in the concentrations of both primary bile acid conjugates between the control groups, and patients with gallstones and poorly functioning gallbladders. Patients with nonfunctioning gallbladders had higher values during the first hour, and lower values thereafter. Surprisingly whereas there was no significant difference between the groups at zero time, SBA values were significantly higher at 15 and $30 \mathrm{~min}$ after the meal in patients with non-functioning gallbladders compared to the other two groups. The mean times at which peak values for cholic and chenodeoxycholic acids were noted were 83 and $90 \mathrm{~min}$ in the control group, 70 and $75 \mathrm{~min}$ in patients with nonfunctioning gallbladders, and 96 and $100 \mathrm{~min}$ in patients with gallstones. A large overlap was noted between groups.

\section{POSTPRANDIAL PROFILES BEFORE AND AFTER CHOLECYSTECTOMY}

Serum bile acid values are given in Table 2 . For both conjugates mean values were greater after cholecystectomy and the difference between pre- and postoperative specimens became greater as the study progressed and became significant $(p<0.05)$ at 105 $\mathrm{min}$ and $120 \mathrm{~min}$.

\section{Discussion}

Serum bile acids are influenced by a number of variables including pool size, gallbladder contraction, intestinal transit, intestinal absorption, hepatic blood flow, and first pass clearance. The influence of many of these factors will become greater immediately after a meal. Thus it is not surprising that whereas fasting SBA bile acid values fall within a narrow range, the range of values becomes progressively large after meals. The scatter was even greater after $2 \mathrm{~h}$ in the few subjects in whom samples were collected for $4 \mathrm{~h}$. This confirms our previous findings ${ }^{5}$ and emphasises that postprandial bile acid values should be interpreted with caution. The wide scatter between normal individuals might be expected to mask differences due to gallbladder disease, and clearly SBA values are of no use in the assessment of gallbladder function.

The higher early postprandial values in subjects with non-functioning gallbladders might reflect the larger component of the pool within the enterohepatic circulation under those circumstances and a greater contribution of a gastric phase of biliary tract emptying. No difference was observed between the control group and those with functioning gallbladders and gallstones, although greater postprandial gallbladder emptying has been described in the latter situation. ${ }^{6}$

The concept of a non-functioning gallbladder as defined in this study is unlikely to be absolute, and it is probable that part of the bile acid pool is retained in the gallbladder in the preoperative group. The larger circulating bile acid pool may account for the higher late postprandial values found in the postoperative group.

We wish to thank Dr G Nicholson for help in collecting serum samples, and Ms M Hughes for typing the manuscript. CRP was supported by the Scottish Hospitals Endowment Research Trust.

\section{References}

' Bouchier IAD, Pennington CR. Serum bile acids in hepatobiliary disease. Gut 1978;19:492-6.

${ }^{2}$ Banes S, Gallo GA, Trash DB, Morris JS. Diagnostic value of serum bile acid estimations in liver disease. J Clin Pathol 1975;28:506-9.

${ }^{3}$ Hofmann AF. The enterohepatic circulation of bile acids in man. Clin Gastroenterol 1977;6:3-24. 
4 Baqir YA, Murison J, Ross PE, Bouchier IAD. Radioimmunoassay of primary bile salts in serum. J Clin Pathol 1979;32:5604.

${ }^{5}$ Pennington CR, Ross PE, Bouchier IAD. Fasting and postprandial serum bile acid concentrations in normal persons using an improved GLC method. Digestion 1978;17:56-62.

- Maudgal DP, Kupfer RM, Zentler-Munro PL, Northfield TC.
Postprandial gall-bladder emptying in patients with gallstones. Br Med J 1980;i:141-3.

Requests for reprints to: Dr CR Pennington, Medical Unit, Kings Cross Hospital, Dundee, Scotland.

\section{The June 1982 issue}

\section{THE JUNE 1982 ISSUE CONTAINS THE FOLLOWING PAPERS}

Morphological characteristics and distribution patterns of epithelial cells in the cytological diagnosis of gastric cancer JENNIFER A YOUNG, HELENA E HUGHES, DJ HOLE

Heterotopic gastric mucosa in the duodenum AM LESSELLS, DF MARTIN

Increased tissue concentrations of histamine in the duodenal mucosa of children with coeliac disease DN CHALLACOMBE. PD DAWKINS

Biopsy findings in malignant histiocytosis presenting as lethal midline granuloma K AOZASA

Villous atrophy with crypt hyperplasia in malignant histiocytosis of the nose K AOZASA

Primary endocrine carcinoma of the parotid salivary gland associated with a lung carcinoid: a possible new association V EUSEBI, S PILERI, L USELLINI, A GRASSIGLI, C CAPELLA

Systemic mastocytosis, myelofibrosis and portal hypertension AH SAWERS, J DAVSON, JOAN BRAGANZA, CG GEARY

A flexible microprocessor system for the measurement of cell size JOAN M ROUND, DA JONES, RHT EDWARDS

Value of plasma calcium, phosphate, and alkaline phosphatase measurements in the diagnosis of histological osteomalacia H PEACH, JULIET E COMPSTON, S VEDI, LWL HORTON

Interrelations between cerebrospinal fluid and plasma inorganic ions and glucose in patients with chronic renal failure IF PYE, GM ABER

Serum gamma-glutamyltransferase and alkaline phosphatase in rheumatoid arthritis RJ SPOONER, DH SMITH, DOROTHY BEDFORD, PR BECK

A rapid method for staining inclusions of Chlamydia psittaci and Chlamydia trachomatis RM WOODLAND, JAYSHREE MALAM, S DAROUGAR
Determination of specific $\operatorname{IgA}$ antibodies to varicella zoster virus by immunoperoxidase assay H HAIKIN, I SAROV

Evaluation of a micromethod gallery (API Staph) for the identification of staphylococci and micrococci RR MARPLES, JF RICHARLSON

An ELISA test for the detection of antibodies to Legionella pneumophila TG WREGHITT, J NAGINGTON, J GRAY

Antithrombin III and fibrinogen degradation product (fragment $E$ ) in diabetic nephropathy $v$ CHAN, CK YEUNG, TK CHAN

Acquired dysfibrinogenaemia in liver disease $\mathrm{JL}$ FRANCIS, DJ ARMSTRONG

Anticoagulant antibodies in the synovial membranes of patients suffering from haemophilia, rheumatoid arthritis and other rheumatic disorders SG RAINSFORD, A ARONSTAM, EJ HOLBOROW, DS McLELLAN

Comparative study of the Fenwal and Pall microaggregate filters used for the production of leucocyte-poor blood JG TRELEAVEN, KG PATTERSON, J BLAGDON

Comparison of lymphocyte transformation and macrophage migration inhibition tests in the detection of beryllium hypersensitivity WR WILLIAMS, W JONES WILLIAMS

\section{Technical methods}

"Cell-block" technique for fine needle aspiration biopsy PN KARNAUCHOW, RE BONIN

Ferrography-a new method for isolation of particles from biological fluids JA HUNTER, GH MILLS, RD STURROCK

\section{Letters to the editor}

Copies are still available and may be obtained from the PUBLISHING MANAGER,

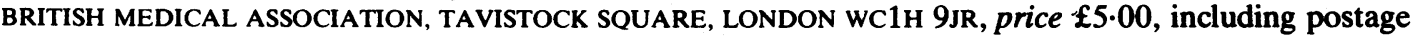

